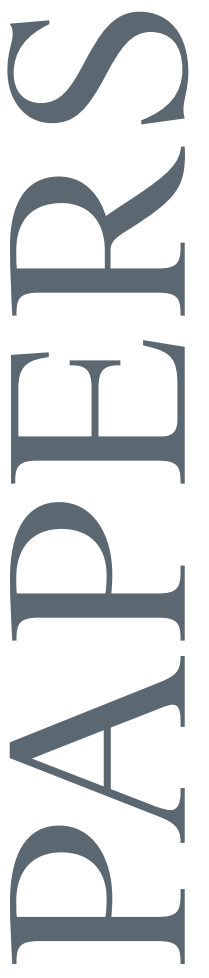

EAST-WEST CENTER WORKING PAPERS

Economics Series

No. 135, November 2013

Is the Information Technology Agreement Facilitating Latecomer Manufacturing and Innovation? India's Experience

Dieter Ernst

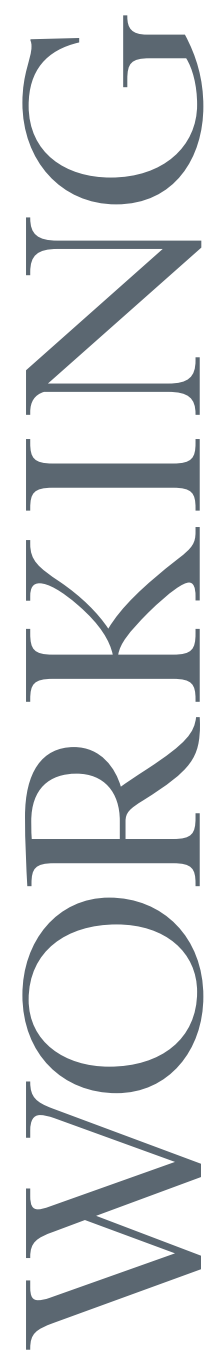

25 $\frac{\text { E A S T - W E S T C E N T E R }}{\text { Collaboration - Expertise - Leadership }}$ 


\title{
Is the Information Technology Agreement Facilitating Latecomer Manufacturing and Innovation? India's Experience
}

\author{
Dieter Ernst
}

East-West Center Working Papers is an unreviewed and unedited prepublication series reporting on research in progress. The views expressed are those of the author and not necessarily those of the Center. East-West Center Working Papers are circulated for comment and to inform interested colleagues about work in progress at the Center.

Working Papers are available online for free at EastWestCenter.org/ewcworkingpapers. To order print copies ( $\$ 3.00$ each plus shipping and handling), contact the Center's Publication Sales Office.

The East-West Center promotes better relations and understanding among the people and nations of the United States, Asia, and the Pacific through cooperative study, research, and dialogue. Established by the US Congress in 1960, the Center serves as a resource for information and analysis on critical issues of common concern, bringing people together to exchange views, build expertise, and develop policy options.

The Center's 21-acre Honolulu campus, adjacent to the University of Hawai'i at Mānoa, is located midway between Asia and the US mainland and features research, residential, and international conference facilities. The Center's Washington, DC, office focuses on preparing the United States for an era of growing Asia Pacific prominence.

The Center is an independent, public, nonprofit organization with funding from the US government, and additional support provided by private agencies, individuals, foundations, corporations, and governments in the region.

\section{EastWestCenter.org/publications}

Publication Sales Office| East-West Center 1601 East-West Road | Honolulu, Hawai'i 96848-1601

Tel: 808.944.7145 | Fax: 808.944.7376

EWCBooks@EastWestCenter.org
Dr. Dieter Ernst, East-West Center senior fellow, is an authority on global production networks and $\mathrm{R} \& \mathrm{D}$ internationalization in hightech industries and on industrial and innovation policies in the US, China, India, and other emerging economies, with a focus on standards and intellectual property rights. He serves as a scientific advisor to the US National Academies, governments, private companies, the World Bank, and other international organizations.

Publications include Fast Tracking India's Electronics Manufacturing Industry: Business Environment and Industrial Policy (2013); America's Voluntary Standards System-A "Best Practice" Model for Asian Innovation Policies (2013); Indigenous Innovation and Globalization: The Challenge for China's Standardization Strategy (2011) [now published in Chinese]; China's Innovation Policy Is a Wake-Up Call for America (2011); A New Geography of Knowledge in the Electronics Industry? Asia's Role in Global Innovation Networks (2009); Can Chinese IT Firms Develop Innovative Capabilities within Global Knowledge Networks? (2008); China's Emerging Industrial EconomyInsights from the IT Industry (with Barry Naughton) 2007; Innovation Offshoring-Asia's Emerging Role in Global Innovation Networks (2006); "Complexity and Internationalization of Innovation: Why is Chip Design Moving to Asia?," International Journal of Innovation Management (2005); International Production Networks in Asia: Rivalry or Riches? (2000); and Technological Capabilities and Export Success-Lessons from East Asia (1998).

An earlier version of the paper was presented at the E15 Expert Group on Trade and Innovation meeting in Geneva on "Strengthening the Multilateral Trading System," co-sponsored by the International Center for Trade and Sustainable Development (ICTSD), IMD Lausanne, and the Evian Group, October 3-4, 2013. 


\title{
Is the Information Technology Agreement (ITA) \\ Facilitating Latecomer Manufacturing and Innovation? ${ }^{1}$ \\ India's Experience \\ by
}

Dieter Ernst, East-West Center, Honolulu

\begin{abstract}
A defining characteristic of today's international trading system is that plurilateral trade agreements like the Information Technology Agreement (ITA) are gaining in importance relative to the gridlocked Doha round of multilateral trade negotiations. These more selective trade agreements pose new and so far little understood challenges for the governance of the international trading system, especially with regard to the distribution of liberalization gains among participants which differ in their stage of development, their institutions, and their resources and capabilities.

The paper examines India's experience with ITA. Initially, the main concern was to attract inward FDI and to facilitate the growth of its then still nascent IT services industry. For electronics manufacturing however, the analysis shows that gains from trade liberalization were overshadowed by substantial costs - with rising electronics imports inflating the country's current account deficit to unsustainable record highs, while eroding domestic electronic manufacturing and innovation.

To improve reciprocity in the distribution of gains from ITA, the paper suggests that latecomers like India deserve, under certain conditions, special and differentiated treatment. In turn, these countries need to agree to reforms that reduce investment barriers in their domestic industries, such as restrictive regulations and discrimination against foreign direct investment.
\end{abstract}

\footnotetext{
${ }^{1}$ An earlier version of the paper was presented at the E15 Expert Group on Trade and Innovation meeting in Geneva on "Strengthening the multilateral trading system", co-sponsored by the International Center for Trade and Sustainable Development (ICTSD), IMD Lausanne, and the Evian Group, October 3 and 4, 2013.
} 


\begin{abstract}
About the author
Dieter Ernst, East-West Center senior fellow, is an authority on global production networks and R\&D internationalization in high-tech industries and on industrial and innovation policies in the US, China, India, and other emerging economies, with a focus on standards and intellectual property rights. Dr. Ernst served as a member of the US National Academies' Committee on Global Approaches to Advanced Computing; a senior advisor to the OECD, Paris; research director of the Berkeley Roundtable on the International Economy (BRIE) at the University of California at Berkeley; professor of international business at the Copenhagen Business School; and scientific advisor to governments, private companies and international institutions.
\end{abstract}

Publications include Fast Tracking India's Electronics Manufacturing Industry: Business Environment and Industrial Policy (2013); America's Voluntary Standards System-A “Best Practice” Model for Asian Innovation Policies (2013); Indigenous Innovation and Globalization: The Challenge for China's Standardization Strategy (2011) [now published in Chinese]; China's Innovation Policy Is a Wake-Up Call for America (2011); A New Geography of Knowledge in the Electronics Industry? Asia's Role in Global Innovation Networks (2009); Can Chinese IT Firms Develop Innovative Capabilities within Global Knowledge Networks? (2008); China's Emerging Industrial Economy-Insights from the IT Industry (with Barry Naughton) 2007; Innovation Offshoring-Asia's Emerging Role in Global Innovation Networks (2006); "Complexity and Internationalization of Innovation: Why is Chip Design Moving to Asia?," International Journal of Innovation Management (2005); International Production Networks in Asia: Rivalry or Riches? (2000); and Technological Capabilities and Export Success-Lessons from East Asia (1998).

\title{
Acknowledgments
}

Comments are gratefully acknowledged from Ahmed Abdel Latif (International Centre for Trade and Sustainable Development/ICTSD), Suzanne Berger (MIT, Production in the Innovation Economy project/PIE), Jorge Contreras (American University Washington, College of Law), Rana Hasan (Asian Development Bank New Delhi), Derek L. Hill (National Science Foundation), Partha Mukhopadhyay (Centre for Policy Research, New Delhi), Marcus Noland (Peterson Institute for International Economics and East-West Center), Peter Petri ( Brandeis University and East-West Center), Michael G. Plummer (Johns Hopkins University SIAS, Bologna, and East-West Center), Pedro Roffe (International Centre for Trade and Sustainable Development/ICTSD), and Willy Shih (Harvard Business School). 


\section{Overview of topic and why it is important}

A defining characteristic of today's international trading system is that plurilateral trade agreements ("plurilaterals") are gaining in importance relative to the gridlocked Doha round of multilateral trade negotiations. Examples are the WTO Government Procurement Agreement $(\mathrm{GPA})^{2}$, the Information Technology Agreement (ITA), and the recent emphasis on megaregional trade agreements, such as the Trans-Pacific Partnership Agreement (TPP) and the Transatlantic Trade and Investment Agreement (TTIA) ${ }^{3}$.

In contrast to multilateral WTO agreements, where all WTO members are party to the agreement, a plurilateral agreement implies that WTO member countries have a choice to agree to new rules on a voluntary basis. Apart from getting around the "decision-making ordeal of the WTO", the main purpose of plurilateral agreements is to respond "to the changing needs of industries with agility" by “... [a]llowing flexibility in the choice of participants" 4 .

The resultant rising complexity of international trade rules poses new and so far little understood challenges not only for the governance of the international trading system but also for national policies that seek to enhance international competitiveness through productivity-enhancing industrial manufacturing and innovation.

We know even less about the challenges that those more selective trade agreements are going to pose for countries which are latecomers to industrial manufacturing and innovation ${ }^{5}$. Will plurilaterals help to accelerate latecomer industrial manufacturing and innovation by narrowing the gap in productivity and income relative to leading industrialized countries? Or will, as opponents from developing countries fear, “...their interests... be neglected as the major trading powers steam ahead without them, in the worst case potentially 'imposing' plurilateral outcomes on them at some future date, ... [while]... forging new standards that developing countries will find difficult to implement ... with ... implications for loss of market access" ${ }^{6}$ ?

\footnotetext{
${ }^{2}$ WTO-GPA opens up government procurement markets only to firms from signatory states and does not provide MFN treatment to non-members. See http://www.wto.org/english/tratop e/gproc e/gp gpa e.htm

${ }^{3}$ For an economic impact analysis of TPP, see Petri, P.A., M.G. Plummer and F. Zhai, 2012, The Trans-Pacific Partnership and Asia-Pacific Integration: A Quantitative Assessment, Peterson Institute for International Economics and East-West Center Policy Analyses in International Economics No. 98, November.

${ }^{4}$ Nakatomi, M., 2013, Plurilateral Agreements: A viable alternative to the WTO?, presentation at the WTO, March 11, http://www.wto.org/english/res e/reser e/wts future2013 e/Nakatomi.pdf :page 8. The author is Special Advisor to JETRO

${ }^{5}$ See however the insightful analysis of suggested intellectual property rights (IPR) provisions in TPP and their potential impact on developing countries in Flynn, S. et al, 2011, Public Interest Analysis of the US TPP Proposal for an IP Chapter, Program on Information Justice and Intellectual Property, American University Washington College of Law, December 6, chapter V. Patent and Data-Related rights). See also Armstrong, S., 2012, Trans-Pacific Partnership: the good, the bad and the ugly, paper presented to the CNCPEC Seminar on TPP 2012, Progress and Challenges, 7 December 2012, Beijing.

${ }^{6}$ Draper, P. and M. Dube, 2013, Plurilaterals and the Multilateral Trading System. An Issue Brief for the ICSTD Expert Group on Preferential Trade Agreements, ICSTD and IDB, Geneva: page 4.
} 
The paper seeks to shed light on this question, by examining India's experience with trade liberalization through the Information Technology Agreement (ITA). The analysis focuses on ITA's impact on manufacturing and innovation in India's electronics industry ${ }^{7}$.

Some basic definitions are in order to establish that manufacturing and innovation are closely intertwined, especially in a technology-intensive industry like electronics. Innovations convert ideas, inventions, and discoveries into new products, services, processes, and business models. Radical breakthrough discoveries and inventions through scientific research are only the tip of the iceberg ${ }^{8}$. Of critical importance are "industrial innovations" that allow for new ways of manufacturing existing products (e.g. with new materials; 3D Printing) as well as for manufacturing new products derived from new ideas, discovery, and inventions (e.g., implanted sensors). This implies that a country can only aspire to become successful in industrial innovation if it has developed a strong manufacturing industry.

In short, without large-scale advanced manufacturing facilities which can draw on an integrated domestic industrial value chain, even the most sophisticated R\&D capabilities are of little use to generate innovations. Recent research in the US demonstrates that excessive reliance on offshore manufacturing and the resultant decline in domestic manufacturing erodes the country's industrial innovation system ${ }^{9}$. This finding applies even more to India's electronics industry, given that its reliance on imports and on offshore manufacturing (mainly in China) is extremely high.

India's experience with trade liberalization through international trade agreements has two sides. Some sectors like IT services, car components and generic pharmaceuticals have clearly benefitted from India's WTO membership. As far as electronics manufacturing is concerned however, an important finding of this paper is that the gains from trade liberalization were overshadowed by substantial costs ${ }^{10}$. The resultant inverted tariff structure has eroded domestic electronics manufacturing, stifled innovation, and boosted electronics imports, inflating the country's current account deficit to unsustainable record highs. ${ }^{11}$ In turn, a weakened and stagnating industrial manufacturing industry is severely constraining India's innovation capacity in this industry.

\footnotetext{
${ }^{7}$ Throughout the paper, the term "electronics industry" is used as a shorthand to cover all segments of the information and communications technology industry.

${ }^{8}$ Ernst, D., 2009, A New Geography of Knowledge in the Electronics Industry? Asia's Role in Global Innovation Networks, Policy Studies, no. 54 , East-West Center, Honolulu: Chapter 2 - Conceptual Framework: Innovation and Innovative Capabilities.

${ }^{9}$ See for instance Pisano, G.P. and W.C. Shih, 2012, Producing Prosperity. Why America Needs a Manufacturing Renaissance, Harvard Business Review Press, Boston, Mass., chapter 5.

${ }^{10}$ An earlier insightful analysis of India's experience with ITA emphasizes "the perils of promoting ICT use by neglecting its production, Joseph, K.J. and G. Parayil, 2006, Trade Liberalization and Digital Divide. An Analysis of the Information Technology Agreement of WTO, Center for Development Studies Working Paper 381, July

${ }^{11}$ According to the revised latest Ministry of Commerce data, electronic imports have increased by almost $21 \%$ from fy2011 to fy 2012. As a result, the electronics industry is the third most important driver of the country's record current account deficit, after petroleum, crude and products, and gold.
} 
This finding raises interesting questions for the study of trade and innovation. One could for instance ask whether the Indian electronics industry would be in better shape today if India had not signed on to ITA, and if not, whether the main culprit would be domestic policy that failed to unblock the barriers to investment and growth in electronics manufacturing. The findings of the paper certainly do not exonerate the responsibility of the Indian Government. There is ample evidence that existing restrictive regulations and the largely dysfunctional implementation of support policies of the past have constrained investment and growth of India's domestic electronics manufacturing ${ }^{12}$.

One could also ask whether the contraction of India's electronics industry in response to trade liberalization has reduced India's welfare, or whether this contraction simply indicates that an inefficient protected industry could no longer survive without fundamental transformations ${ }^{13}$. Furthermore, a related question would be whether India's progress in IT services, chip design and R\&D outsourcing has benefitted from ITA and, if so, whether this could compensate for the negative performance of electronics manufacturing in terms of employment generation, capability development and productivity-enhancing innovation ${ }^{14}$. In addition, one could ask whether the findings of a negative impact of ITA are sector-specific, and are shaped by specific characteristics of electronics manufacturing ${ }^{15}$.

These are important questions but they are beyond the scope of this brief Think Piece that focuses on reforms of the multilateral trading systems that are conducive for the spread of industrial innovation. A central proposition is that the success or failure of trade liberalization is determined by the strength of a country's economic institutions, its market size and sophistication, and the managerial and technological capabilities of its firms. ${ }^{16}$

\footnotetext{
${ }^{12}$ For an in-depth analysis, see Ernst, D., forthcoming, Fast tracking the Growth of India's Electronics Industry Regulatory Reform and Support Policies, a study prepared for the World Bank.

${ }^{13}$ To answer that question about the ultimate welfare effects would require a general equilibrium analysis. For a typical example, albeit based on highly aggregated and outdated data, see Topalova, P., 2007, Trade Liberalization and Firm Productivity: The Case of India, March , http://www.etsg.org/ETSG2007/papers/topalova.pdf. See also the earlier widely quoted study by Krishnaa, P. and D. Mitrab, 1998, Trade liberalization, market discipline and productivity growth: new evidence from India, Journal of Development Economics. Volume 56, Issue 2, August: Pages 447-462.

${ }^{14}$ However, a defining characteristic of information and communications technology is that productivityenhancing innovation necessitates close interactions between knowledge generation (research), technology development, scale-up (pilot line \& prototypes) and globally competitive manufacturing. While some of these interactions can occur across national borders through global production and innovation networks, no country can succeed without a critical threshold of domestic manufacturing, especially for components. Hence, growth in IT services and chip design is unlikely to compensate for the absence of sound domestic electronics manufacturing capabilities.

${ }^{15}$ In contrast to the misery of electronics manufacturing, India in fact excels in generic pharmaceuticals, car components and information services.

${ }^{16}$ This is in line with recent research on India's liberalization as well as research which emphasizes the importance of technological capabilities and the organization of credit and labor markets. See Aghion, P., R. Burgess, S. Redding, F. Zilibotti, 2006, The Unequal Effects of Liberalization: Evidence from Dismantling the License Raj in India, NBER Working Paper No. 12031, February: 31 pages; and Acemoglu, D., P. Aghion and F. Zilibotti (2006), “ Distance
} 
India indeed needs to overcome very substantial "latecomer disadvantages" that result from lagging behind major trading powers in the development of economic institutions and capabilities that are essential for advanced industrial manufacturing and innovation. As emphasized by Raghuram Rajan, India's new Central Bank governor, India of course bears the primary responsibility for correcting the above latecomer disadvantages, and the government needs to better align domestic policies in order to unblock the barriers to investment and growth in the electronics industry ${ }^{17}$. In fact, as documented in the afore-mentioned World Bank study, the Indian government seeks to fast track the development of India's electronics manufacturing industry through regulatory reform and industrial support policies.

Yet the challenge is such that, even under the best of circumstances, it would take a long time to substantially reduce the gap in costs and capabilities that currently separates India from the leading trading powers ${ }^{18}$. There is thus an urgent need for reforming the multilateral trading system. It is necessary to acknowledge the asymmetric effects that plurilateral agreements like ITA may have on cost structures and capabilities of latecomers like India.

If ITA fails to recognize the different stages of development of participants, this may result not just in zero sum but negative sum outcomes that may end up sparking serious trade conflicts. In line with Mari Pangestu's suggestion, this paper thus argues that plurilateral agreements should allow for special and differential treatment of latecomers. ${ }^{19}$

Differential treatment of latecomers is especially important for the ITA which affects a substantial and rapidly growing part of international merchandise trade and FDI. ITA covers an industry that is an important source of innovation. And in many segments of this industry entry barriers are high due to demanding technology requirements. As long as no solution is found for the unequal distribution of ITA gains, it is unrealistic to expect further progress in trade liberalization in this industry which is critically important for the diffusion of productivityenhancing innovation.

Part two of the paper reviews conflicting perceptions of the distribution of trade liberalization gains. Part three highlights defining characteristics of latecomer economic development that set

to Frontier, Selection, and Economic Growth", Journal of the European Economic Association, 4(1), pp. 37-74, March.

${ }^{17}$ Rajan. R., 2013, Why India Slowed, 30 April, http://www.project-syndicate.org/print/the-democratic-roots-ofindia-s-economic-slowdown-by-raghuram-rajan

${ }^{18}$ According to Partha Mukhopadhyay at New Delhi's Centre for Policy Research, policies to change tariff and duty structures are prey to serious conflicts of interest between the central government and the states, but they may be easier to implement than changing labor laws, while short-term infrastructure issues, like power and transportation could in principle be fixed or at least isolated in specialized clusters. The fundamental longer-term challenge however is to create and continuously upgrade an educated and skilled labor force that is needed to translate innovations into competitive products and services. (Email to the author, dated August 19, 2013)

${ }^{19}$ According to Pangestu, plurilateral agreements “...should promote economic and technical cooperation recognising the different stages of development of participants. Special and differential treatment can be justified in circumstances where participants face challenges in benefitting from an increase in trade.", http://ictsd.org/publications/latest-pubs/dg2013/mari-pangestu/ 
India apart from the major trading powers in the information technology manufacturing industry. Part Four examines India's experience with ITA-1, highlighting negative effects of the inverted tariff structure on import content, domestic production and value-added. Part Five discusses implications for India of a possible expansion of the product list to be covered by ITA-2. The paper concludes with a summary of findings and policy implications.

\section{The Information Technology Agreement (ITA) - Conflicting Perceptions on the distribution of trade liberalization gains}

The ITA went into effect in April 1997 with 29 WTO member countries and now includes 74 WTO members. 36 members are non-OECD member countries, and 35 of those are developing countries $^{20}$. Apart from India, this includes large countries such as China, Egypt, Indonesia, Philippines, Turkey and Vietnam, and middle-income countries, such as Malaysia, Taiwan and Thailand $^{21}$. All of these countries have the potential to become players in the electronics industry. For these countries, the question matters whether ITA facilitates latecomer manufacturing and innovation ${ }^{22}$. India's experience with ITA thus may provide important insights on necessary reforms of ITA that could help to better accommodate the need for special and differential treatment of those countries.

In its current form, ITA provides for zero tariffs for 217 electronics products ${ }^{23}$. The main product groups covered were computers, semiconductors, semiconductor manufacturing and test equipment, telecommunications equipment, software, and scientific instruments ${ }^{24}$.

The US government was a major driving force behind the establishment of ITA. The agreement's agenda was shaped by a core group of developed countries who accounted for nearly all of the original signatories, with Indonesia and Turkey the only developing countries formally adopting the Declaration. Unlike some other plurilateral trade agreements, such as the WTO-GPA (Government Procurement Agreement), which allows exceptions by way of offsets (e.g. defence offsets), the ITA does not allow any exception to the covered products. The only

\footnotetext{
${ }^{20}$ For a list of participants and their date of participation, see WTO, 2012, 15 Years of the Information Technology Agreement. Trade, Innovation and Global Production Networks, World Trade Organization, Geneva: p.107

${ }^{21}$ An important exception is Mexico that has decided that non-membership better fits its economic interest.

${ }^{22}$ Unfortunately, no systematic research seems to exist on the experience of other ITA developing countries. The following publications provide some limited factual information on the ITA experience of China, Malaysia and Egypt: Bora, Bijit, and Liu, Xueping. 2006. "Evaluating the impact of the WTO Information Technology Agreement." WTO Working Paper; US Department of Commerce/Commercial Service in Kuala Lumpur, 2003, Malaysia:

Customs, Taxes and Documentation Requirements for IT Products and Services Imports, http://web.ita.doc.gov/ITI/itiHome.nsf/9b2cb14bda00318585256cc40068ca69/a1a04632abbfd8e485256d270066 abe3 ; Egypt Ministry of Communications and Information Technology, Trade Agreements, http://www.mcit.gov.eg/TeleCommunications/Trade Agreements.

${ }^{23}$ Soon after ITA became effective in April 1997, participants commenced a schedule of phased duty reductions, with all duties slated for elimination by 2000.

${ }^{24}$ Not covered were mainly consumer electronics products, including CRT TV sets, video cameras and photocopiers. For ITA-1 product lists, see http://www.wto.org/english/tratop_e/inftec_e/symp_march07_e/richtering_e.ppt\#309,12,ITA Products and HS 2007
} 
relaxation is to identify certain specified products as sensitive so that they qualify for a phased-in implementation period for extended implementation. India, which signed ITA in 1997, has requested and received such an extension ${ }^{25}$.

ITA has enabled a substantial increase in the trade with electronics products that are covered by the agreement. "Aggressive tariff liberalization facilitated growth in ITA trade from $\$ 1.2$ trillion to $\$ 4.0$ trillion ... [in 2010]."26 Opinions differ however on the distribution of trade liberalization gains. A widely held perception in the US is that "developing countries" are benefiting substantially from trade liberalization through plurilaterals. For instance, Ezell (2012) argues that trade liberalization through ITA is likely to

“...benefit developing countries in three principal ways: 1) reducing tariffs on a broader range of ICT products encourages greater adoption of ICT products that play a key role in spurring economic growth; 2) lower prices realized by reducing tariffs on ICTs increases the productivity of all other industries in a developing economy; and 3) by lowering the price of a key input, the ITA has undergirded development of the burgeoning ICT software and services industries in many developing countries such as India, Indonesia, Malaysia, and the Philippines. "27

Unfortunately, the above argument neglects fundamental differences among ITA participants in the stage of development, in economic institutions, and in their resources and capabilities for manufacturing and innovation. Due to these structural differences, ITA participants differ in their capacity to reap the above potential gains from trade liberalization.

Furthermore, as stated by the US International Trade Commission, “...[t]he paucity of conclusive research on the impact of the ITA on global trade attests to the difficulties in empirically measuring the effects of the ITA and signals that ... considerable discussion and analysis are still needed to determine the magnitude of the ITA's impact on IT trade and technology diffusion." (Anderson and Mohs: 2010: p.41)

Closer to reality are industry insiders and US government officials who argue that leading US MNCs "benefit disproportionally" from ITA-enabled trade liberalization. ${ }^{28}$ There is indeed evidence that for leading US vendors of information and communication technology products,

${ }^{25}$ India and several other developing countries, including Costa Rica, Indonesia, South Korea, and Taiwan, implemented extended duty staging to 2005 on a product-by-product basis as permitted in the ITA Declaration.

${ }^{26}$ Anderson, M. and J. Mohs, 2010, "The Information Technology Agreement: An Assessment of World Trade in Information Technology Products", Journal of International Commerce and Economics, U.S. International Trade Commission, http://www.usitc.gov/publications/332/iournals/info tech agreement.pdf: p.41.

${ }^{27}$ Ezell, S.J., 2012, Boosting Exports, Jobs and Economic Growth by Expanding the ITA, The Information Technology and Innovation Foundation (ITIF), Washington, D.C., March: pages 8 and 9.

${ }^{28}$ Quote from presentation by Greg Slater, Intel's director for Trade and Competition Policy, at an event, hosted by the Information Technology and Innovation Foundation (ITIF) on Boosting Exports, Jobs and Economic Growth by Expanding the ITA, Washington, D.C., March 15, 2013, http://www.itif.org/files/2012-ita-slater.pdf At the same event, Miriam E. Sapiro, Deputy USTR, argued that "ITA has been one of the most successful agreements ever undertaken in the multilateral trading system", as it has boosted US information technology exports. http://www.itif.org/files/2012-sapiro-comments-ita.pdf 
ITA provided significant benefits in terms of growing exports and expanding global production networks.

Take semiconductors, an important product covered by ITA-1. While before 1997, the US share in the worldwide market for semiconductors hovered around $40 \%$, since the signature of the ITA agreement, the US share has moved up to around $50 \%{ }^{29}$. From 2005 to 2009, semiconductors constituted the number one product export from the United States on an aggregate basis, with exports totaling $\$ 48$ billion ( $\$ 10$ billion more than automobile exports, in second place). ${ }^{30}$ And in 2011, U.S. semiconductor producers had global sales of $\$ 152$ billion, representing over one-half of the global semiconductor market ${ }^{31}$.

As for the impact on global production networks, research by the U.S. International Trade Commission finds that ITA-1 boosted FDI by MNCs in China which "had a major role in China's accelerating ITA exports, as multinational corporations sought to reduce costs by directly adding capacity in China. Once China joined the WTO, products exported from China were guaranteed MFN access to other countries, providing strong incentives for multinational corporations to establish production and assembly operations in China." (Anderson and Mohs, 2010: p.17)

\section{Latecomer Manufacturing and Innovation - Fundamental Flaws of India's electronics industry}

The study of trade liberalization through plurilateral trade agreements needs to be nested in the larger context of latecomer manufacturing and innovation.

The distinction between "latecomers" and incumbent "leaders" who have accumulated "firstmover advantages" goes back to debates among economic historians on how "relative economic backwardness" in the $19^{\text {th }}$ century has shaped the patterns and strategies of industrialization of countries such as the US, Germany, Japan and Russia ${ }^{32}$. The key difference is not in time, but in the stage of development of market, institutions and capabilities and the resultant constraints to investment, growth and productivity-enhancing innovation. Under certain conditions, economic advantages are conferred on countries which are latecomers to industrial development ${ }^{33}$. At the

\footnotetext{
${ }^{29}$ Slide 5 in http://www.aaas.org/spp/rd/presentations/20110218PatrickWilson.pdf. Market share based on headquarters of seller.

${ }^{30}$ Semiconductor Industry Association, "Doubling Semiconductor Exports Over the Next Five Years," (analysis, SIA, San Jose, CA, June 17, 2010), http://www.sia-online.org/clientuploads/directory/ DocumentSIA/ Export/Doubling_Exports_Paper_0610.pdf

31 USITC, hearing transcript, November 8, 2012, 39,41 (testimony of Ian Steff, Semiconductor Industry Association)

32 The classical source remains Gerschenkron, A., 1962, Economic Backwardness in Historical Perspective: A Book of Essays, Cambridge, Mass, The Belknap Press.

${ }^{33}$ The basic idea is that those who are behind have the potential to make a larger leap. According to a classical study, "the larger the technological and, therefore, the productivity gap between leader and follower, the stronger the follower's potential for growth in productivity: and, other things being equal, the faster one expects the follower's growth rate to be. Followers tend to catch up faster if they are initially more backward." (Abramovitz, 1989: p.221)
} 
same time however, empirical research has identified a great variety of entry barriers confronting industrial latecomers ${ }^{34}$.

India's electronics industry provides ample examples of such latecomer disadvantages.

Compared to its main competitors, local production struggles with substantial cost disadvantages ("disabilities") which constrain investment in plants and equipment, technology absorption, capability development and innovation. There is a huge gap between the rapid growth of domestic demand and the practically stagnant domestic production, and this gap is projected to increase further ${ }^{35}$.

A defining characteristic of India's electronics market is that a handful MNCs dominate without engaging in substantial domestic manufacturing in India (whether directly or through EMSs), with the exception of low-value-added final assembly. Those MNCs can rely on their extended global production networks to source the relevant products for the Indian market from low-cost production sites, primarily in China ${ }^{36}$.

Where local Indian firms seek to compete with MNCs for the India market, they follow the same pattern of sourcing their products from offshore production sites in China. Indian firms thus have to compete on the "China price", relying on offshore outsourcing to China-based electronics manufacturing service providers (EMSs).

Given the weakness of domestic production, India's growing domestic demand for electronic products results in rising imports, while bottlenecks abound across the industry's value chain, causing excessive import dependence for key components. In 2011, imports counted for $63.6 \%$ of India's consumption of electronics products, and 51\% for electronic components. By 2015, the share of imports is expected to increase to $65 \%$ and $61 \%$ respectively (Frost \& Sullivan, 2013).

India's liberalization of information and telecom services has boosted the demand for telecom equipment, but this has not led to the development of a domestic telecom manufacturing industry. Instead, global telecom equipment vendors such as Alcatel, Ericcson, and increasingly Huawei and ZTE have been the primary beneficiaries. And consumer electronics, the largest segment of India's electronics market is dominated by MNCs, especially Panasonic, Sony, LG, and Samsung. Over the last few years, these companies have substantially decreased domestic production, and rely now overwhelmingly on imports from China. As for domestic vendors, they are even less reliant on domestic production - they almost completely source from China.

\footnotetext{
${ }^{34}$ For a detailed analysis, see Ernst, D. and D. O'Connor, 1992, Competing in the Electronics Industry: The Experience of Newly Industrialising Economies, OECD Development Centre Studies, OECD, Paris.

${ }^{35}$ Frost \& Sullivan, 2013, Indian Electronic System Design and Manufacturing Industry (2011-2015). Growth, Trends and Forecast, India Semiconductor Association, Bangalore: page 36.

${ }^{36}$ In addition to China's substantial cost advantages, what matters most for MNCs is that they can benefit from the accumulated capabilities in China for rapid and low-cost scaling up of sophisticated production lines that exceed by far India's current capabilities. See the chapter by MIT's Ed Steinfeld on China's manufacturing scaling-up capacity in: Locke, R.M. and R. Wellhausen (eds), forthcoming, Production in the Innovation Economy, The MIT Press
} 
It is important to emphasize that India's thriving integrated circuit design sector remains largely disconnected from the India market. Most of the design work is done for MNCs and the design is taken back to their home country where decisions are made where to locate manufacturing, many times ending up in places like Shenzhen. As a result, India is not benefiting from its rich pool of sophisticated IC design engineers, as this pool remains disconnected from the development of the domestic electronics manufacturing industry.

In short, deep integration of electronic design capabilities into global R\&D networks is paired in India with almost no integration into the domestic electronics manufacturing value chain. For instance, all major EDA tool providers for chip design have large facilities in India. But all of them are $100 \%$ focused on export markets. Hence, little of these capabilities are likely to disseminate within India.

India faces a fundamental challenge - its electronics industry cannot count so far on a vibrant industrial innovation system which in turn constrains its capacity for productivity-enhancing innovation. For many domestic firms, inadequate size prevents economies of scale and scope, while high costs of doing business, Byzantine regulations, and low domestic value-added constrain profit margins and hence investment in production and R\&D. In addition, larger foreign OEMs and EMSs typically conduct only final assembly in India, and are reluctant to invest in full-scale manufacturing and $R \& D$.

There is ample evidence that India's R\&D system remains stuck at a low level, unable to provide capabilities and innovations that would enable its electronics industry to reap the benefits of ITA liberalization. The most recent Global Innovation Index 2013 provides ample evidence of India's weak industrial innovation capacity - India ranks 66, out of 142 countries, with a total score of 36.2. China on the other hand ranks 35 , with a total score of $44.7^{37}$. According to the Battelle Institute, a primary source of international R\&D date, India's gross expenditure on research and development (GERD) was $0.85 \%$ of GDP in 2012 (compared to $1.6 \%$ in China), a figure essentially unchanged since $2000^{38}$.

Industrial research outputs in terms of patents, remain limited. India has one of the smallest ratios of scientists and engineers per million people (137/million people) compared to other countries in the region, such as China and South Korea, which produce larger numbers of engineers each year than any other countries in the world. This reflects the hugely variable quality of India's higher education, ranging from excellent to inadequate ${ }^{39}$.

\footnotetext{
${ }^{37}$ Cornell University, INSEAD, and WIPO, 2013, eds, The Global Innovation Index 2013. The Local Dynamics of Innovation, Geneva, Ithaca, and Fontainebleau

${ }^{38}$ The 2013 R\&D Magazine/Battelle Global R\&D Funding Forecast, http://www.rdmag.com/digitaleditions/2012/12/2013-r-d-magazine-global-funding-forecast. This finding is accentuated by the fact that China's GDP is much larger than India's and is growing substantially faster.

${ }^{39}$ Of particular concern is the dearth of qualified faculty, as top graduates prefer to go abroad or work for the financially much more attractive affiliates of global corporations. Agarwal, P., 2006, Higher Education in India. The Need for Change, Indian Council for Research on International Economic Relations (ICRIER), Working Paper 180, New Delhi http://www.icrier.org/pdf/ICRIER WP180 Higher Education in India_pdf
} 
Most importantly, a crumbling basic education system and a persistently high adult illiteracy (32\% for men, but $55 \%$ for women) indicate severe limitations to the quality of India's workers who are needed to translate innovations into competitive products and services ${ }^{40}$.

In the final analysis, the misery of India's electronics manufacturing industry points to a broader challenge. India's economic institutions, both public and private, were largely designed for a time before India was opened to the global economy. These institutions are ill-equipped to cope with the requirements of transforming India into an internationally competitive industrial economy that could reap the benefits of ITA -related trade liberalization ${ }^{41}$.

\section{India's experience with ITA}

When India signed ITA in 1997, the main concern was to attract inward FDI and to facilitate the growth of its then still nascent IT services industry. ITA participation was also viewed as an important catalyst for extending further India's liberalization drive.

At the same time however, India's participation in ITA has acted as an important barrier to the development of India's domestic electronics manufacturing industry. It is important to emphasize that India joined ITA from a position of weakness in this industry. The country was heavily relying on electronics imports, but had no significant domestic electronics industry. As part of the government's liberalization drive, India actually volunteered quite substantial tariff concessions $^{42}$.

This contrasts with China's approach, which joined ITA only in 2003. In contrast to India, China entered the ITA from a position of strength. "China was ... [already]... a leading manufacturer and trader of IT products prior to joining the ITA and deeply engaged in the global IT production chain even before tariff liberalization." (Anderson and Mohs, 2012: p.7) When China joined the ITA in 2003, its per capita GDP $(\$ 1,270)$ was three times higher than that of India's 1997 per capita GDP $(\$ 427.2)^{43}$. By 2003, when China entered the ITA, it was already the third largest exporter and the fourth largest importer of ITA products ${ }^{44}$.

\section{The inverted tariff structure syndrome}

\footnotetext{
${ }^{40}$ Dahlman, C. and A. Utz, 2005, India and the Knowledge Economy: Leveraging Strengths and Opportunities, The World Bank, Washington, D.C., June: chapter 3. Recent research shows that "the persistently high illiterary rate is falling,... and almost none of the new entrants to the urban labor force is illiterate but a majority of them do not complete school." Partha Mukhopadhyay, email to the author, August 19, 2013.

41 See Kelkar, Vijay. (1999). “India's Emerging Economic Challenges,” Economic and Political Weekly, August 14, pp. 2326-29).

${ }^{42}$ The largest tariff concessions to ITA, based on pre-ITA bound rates, were by India (66.4 percent), way ahead of Thailand (30.9 percent), and Turkey (24.9 percent). India also stood out in average applied-tariff reductions, where India's tariffs were reduced from a pre-ITA level of 36.3 percent, compared to China where average applied-tariff reductions started from a level of 12.7 percent. (Anderson and Mohs, 2012: p.4) ${ }^{43}$ http://search.worldbank.org/data?qterm=India\%20per\%20capite\%20GDP\%20for\%201997\&language=EN 44 In 2004, China expanded its market share, becoming the world's largest exporter of ITA products. In 2005, China surpassed both the EU and the United States to become the largest country in terms of overall ITA trade. (Anderson and Mohs, 2012: p.17)
} 
As joining ITA led to a reduction of India's tariffs for final products to zero or close to zero, this has led to an acceleration of ITA imports. In 2000, 96 product lines were reduced to zero tariff, and in 2005, 121 product lines were reduced to zero tariff. While India's ITA imports grew by $18 \%$ annually between 1997 to 2000, their growth rate increased to nearly $38 \%$ between 2001 and $2005 .^{45}$

An immediate impact has been an increase of the import content of the raw material consumption of India's electronics industry over the last 7 years from $50.48 \%$ to $55.86 \%{ }^{46}$. Furthermore, India's electronics imports under HS code 85 have grown faster than India's electronics consumption ${ }^{47} 48$. Between fy 2010-11 and fy 2012-13, India's imports grew especially fast for integrated circuits $(82.02 \%)$, the second largest electronics import category ${ }^{49}$.

In principle, trade deficits are not always negative for economic growth. In fact empirical research points to the importance of imports in boosting productivity ${ }^{50}$. Yet in India's case, local value added of electronics manufacturing is around 7\%, while electronics imports account for almost two thirds of India's consumption of electronics products (Frost and Sullivan: 2013). These imports are a major driver of the country's record current account deficit. Hence, positive productivity effects of rising imports are quite unlikely.

In addition, an analysis of the number of Triadic patent families by applicant's country of residence shows that between 1999 and 2005, India recorded a measly total of 26 such patents. During the same period, China recorded 208 such patents, Korea 4862, and the US 37,907. ${ }^{51}$

In short, the Indian electronics industry has clearly not benefited from participation in the ITA. By implementing zero customs duty on 217 tariff lines of products and their inputs in 2003, ITA has significantly constrained local manufacturing and innovation. Any electronic product that Indian companies have shown competence in has its imported transistors, diodes or capacitors

\footnotetext{
${ }^{45}$ Kallummal, M., 2012, Process of Trade Liberalisation under the Information Technology Agreement (ITA): The Indian Experience, Centre for WTO Studies (CWS) Working paper 200/3, Indian Institute of Foreign Trade, New Delhi: page 15.

${ }^{46}$ Kallummal, 2012: figure 19, page 36. The import content was growing even faster for two strategically important product groups: i) Computers, peripherals \& storage devices - From an already very high import content of $61.76 \%$ in fy 2005 to more than 75\% in fy 2012; ii) Other electronics (which basically can serve as a proxy for electronic components) - From more than 45\% in fy 2005 to almost 53\% in fy 2012.

${ }^{47}$ HS code 85 covers ELECTRICAL MACHINERY AND EQUIPMENT AND PARTS THEREOF; SOUND RECORDERS AND REPRODUCERS, TELEVISION IMAGE AND SOUND RECORDERS AND REPRODUCERS, AND PARTS.

${ }^{48}$ India's consumption of electronics products grew by $14 \%$ from fy 2010 to fy 2012 . During the same period, India's imports of electronics (HS 85) products increased by almost $31 \%$.

${ }^{49}$ India's imports also grew very fast for some electronic components like capacitors (35.9\%), rectifiers and inductors (38.4\%0, and for consumer-related products like video recorders and monitors $(81.11 \%)$, and microphones and loudspeakers (109.1\%). For details, see DGFT website Import Chapter 85 - 2011-...pdf ${ }^{50}$ OECD, 2010, How Imports Improve Productivity and Competitiveness, OECD, Paris, http://www.oecd.org/trade/45293596.pdf

${ }^{51}$ WTO Secretariat data, based on OECD Stat Extracts (27 February 2012), quoted in WTO, 2012, 15 Years of the Information Technology Agreement. Trade, Innovation and Global Production Networks, WTO, Geneva:table 4.1., page 71.
} 
taxed at 14 per cent, while a finished item (such as STB's or low-cost medical equipment) can be shipped in from China at zero per cent ${ }^{52}$.

Specifically, India's inverted tariff structure has leds to a sharp decline in investments in the domestic production of components, raw materials, parts and even electronic sub-assemblies. As a result, the share of domestically manufactured electronic components in India's component consumption has declined from over $50 \%$ in 2005 to an estimated $43 \%$ in $2013^{53}$.

The erosion of domestic electronics manufacturing has drastically increased India's trade deficit in electronics products. For 2009 and 2010, India's average trade deficit for ITA products was \$ 15.54 billion, equaling almost $70 \%$ of India's average trade deficit ${ }^{54}$.

In short, as far as trade is concerned, the costs of ITA for India seem to have substantially exceeded any gains. More importantly, ITA has acted as a fundamental barrier to developing India's domestic electronics manufacturing industry and its innovation capacity. Some observers fear that, with the influx of imports into the domestic markets, due to the zero tariff under the ITA, “...the existing domestic producers may become domestic assemblers and traders in the IT products.” (Kallummal, 2012: p. 15)

In fact, India faces a double whammy: While ITA-related tariff reductions have led to a sharp decline in investments in domestic electronics manufacturing, exports from India at the same time face substantial technical barriers to trade (TBTs) and non-tariff barriers (NTBs) in the US, the EU and Japan ${ }^{55}$. According to recent research, the US, the EU and Japan appear to be the main drivers behind the surge in NTBs and TBTs - Of the total of 456 TBT notifications from 1995 to 2000 by all WTO members, developed countries have submitted 356 notifications, i.e. $78 \%$ of the total notifications (Kallumal, 2012: pages $17 \mathrm{ff}$ ).

\section{Implications for India of a possible expansion of ITA}

In July 2013, ITA members were negotiating in Geneva a possible substantial expansion of the list of products covered by ITA.The Indian government decided not to join the Geneva ITA-2 negotiations ${ }^{56}$.The Indian Government argues that a small group of developed country

\footnotetext{
52 Marwaha, S.K., 2012, "The Experience of Developing ITA Participants INDIA", WTO Symposium on the 15th Anniversary of the Information Technology Agreement, Geneva, May 14 http://www.wto.org/english/tratop_e/inftec_e/symp_may12 e/speaker7marwaha.pdf

${ }^{53}$ ELCINA 2013, ELCOMOS Report 2013: page 11

${ }^{54}$ India's average share of worldwide exports in ITA products during the same period was $0.28 \%$ DeitY data, presented in Marwaha, S.K., 2012, The Experience of Developing ITA Participants: INDIA, ppt presentation at WTO Symposium on the 15th Anniversary of the Information Technology Agreement, Geneva, May 14, http://www.wto.org/english/tratop e/inftec e/symp may12 e/speaker7marwaha.pdf

55 Jauhri, A., 2013, Implementing TB T Agreement. Indian Experience, presentation at the National Workshop On The WTO Agreement on Technical Barriers To Trade, Centre for WTO Studies, Indian Institute of Foreign Trade, New Delhi, Apreil 4-5.

${ }^{56}$ According to the Commerce and Industry Ministry, "India's experience with the ITA-1 has not been encouraging as it has almost wiped out the IT industry from India. After examining the matter in consultation with the nodal
} 
signatories of the ITA, led by the U.S., the European Union and Japan have designed an expanded list with a focus on products where these countries, and especially the US, continue to lead by a wide margin.

In fact, a report of the US International Trade Commission for the US Trade Representative (USTR) identified five priority subsectors of the consolidated draft product list for ITA-2: medical devices; relay and industrial control equipment; optical media, including LED; loudspeakers and handsets; and, most importantly multicomponent integrated circuits (MCOs) ${ }^{57}$ ${ }^{58}$. It is estimated that in 2011, sales of MCOs accounted for between 1.5 and $3.0 \%$ of global semiconductor sales, or an estimated $\$ 1.2$ to $\$ 2.4$ billion ${ }^{59}$. US-ITC selected these subsectors to illustrate "the potential for increased market access opportunities for USA firms as a result of ITA expansion.” (US International Trade Commission, 2013: page VI)

An alternative strategy for India has been proposed by the The Associated Chambers of Commerce and Industry of India (ASSOCHAM) ${ }^{60}$. The Chamber argues that merely resisting the ITA expansion is unlikely to have positive effects for India's electronics industry. Instead, the Indian government should engage in a smart strategy of co-shaping the consolidated product list of ITA-2: "India needs to address the ITA expansion, weighing carefully its long-term as well as short-term objectives in a strategic manner rather than becoming overly influenced by ad hoc approaches and concerns." (ASSOCHAM National WTO Council: p.8)

In this view, non-participation in ITA-2 negotiations comes at a heavy cost. Not only would India lose the option of co-shaping the contents of the new expanded ITA product list. Nonparticipation might also discourage international investors to expand their presence in India, and it might act as a disincentive for existing FDI manufacturing projects to expand and upgrade their facilities.

A close look at the outcome of the July 2013 ITA-2 negotiations in Geneva however raises doubts whether India would have had realistic chances to co-shape the expanded ITA-2 product list. In fact, China was precisely trying to implement such a co-shaping negotiation strategy, but the result of the Geneva meeting was not encouraging. Before the Geneva meeting, China

Ministry i.e. Department of Electronics and Information Technology and other stakeholders, it has been decided, for the present, not to join the negotiations as it will not be in our national interest." Quoted in "India to skip talks on expanding ITA scope", The Hindu, March 13, 2013.

${ }^{57}$ United States International Trade Commission, The Information Technology Agreement. Advice and Information on the Proposed Expansion: Part 2: http://www.usitc.gov/publications/332/pub4382.pdf

${ }^{58}$ MCOs are used in a wide variety of products, including smart phones, tablets, medical devices, household appliances, and car parts such as braking, steering and air bag systems. MCOs thus can be classified under a wide range of HS subheadings. As a result, no one really knows for sure how important MCOs are for US exports.

${ }^{59}$ According to USITC, major US semiconductor firms producing MCOs in the US include Intel, Texas Instruments, Freescale, ON Semiconductor, Analog Devices; and leading fabless chip design companies like Qualcomm, Broadcomm, Nvidia and Cypress Semiconductor.

${ }^{60}$ ASSOCHAM National WTO Council, Observations on 'Expanding the Information Technology Agreement', based on the deliberations at the roundtable held on 20th December 2012, New Delhi, http://view.officeapps.live.com/op/view.aspx?src=http\%3A\%2F\%2Fwww.assocham.org\%2Fdocs\%2FITARoundtable-Observation-Paper 13.2.13.doc ; 
presented a list of sensitive products that called for the removal of 106 products rather than asking for an extended implementation period (so-called "staging"). Under pressure to shorten this list, China on July 17 reduced the list of sensitive products that it wanted not to be part of the ITA-2 to around 90. China's revised list of sensitive products included two product groups that are among the US priorities for ITA-2: MCOs and medical devices.

The following quote from a detailed report in the newsletter Inside U.S. Trade nicely summarizes the ITA core group's response to the China's revised sensitivities list:"

"Following that, the Canadian mission -- which was organizing the meetings in Geneva -- sent out a notice stating that talks previously scheduled for July 18 would not take place, on the basis of the earlier agreement at the ambassador level that talks could not advance without China producing a more "credible" list.

Exactly what constitutes a credible list is something that no member has clearly defined, sources said. But one source said that the chief drivers of the ITA expansion initiative -- the U.S., Japan and the EU -- are clearly targeting a total expansion including about 200 items. That would require China to at least halve its current list of sensitivities.

China was not supportive of suspending the negotiations, and it is unclear whether it will really be able to back off its initial position to that extent. But while some sources charged that China's long list indicated a lack of coordinated domestic consultation -- given what they claimed were the potential benefits China could reap from eliminating some of the tariffs it has asked to exclude -- others said Beijing's position is more nuanced. It may be taking the stance it has because it has industrial policy goals in mind, one source posited. ",61

India faces a similar, albeit more pressing dilemma. If ITA-2 would indeed broaden the product list to include MCOs and medical equipment, this will most likely close any realistic chances for India to develop significant domestic manufacturing capabilities in these subsectors.

\section{Conclusions}

Plurilateral trade agreements, such as the ITA, in principle could strengthen the multilateral trading system, by reducing barriers to trade that have not been adequately addressed in multilateral trade negotiations. From a global welfare perspective, such trade expansion could reinforce the diffusion of innovation ${ }^{62}$.

However, this would require reciprocity in the distribution of gains from the ITA. As this think piece demonstrates, it will not be easy to establish such reciprocity between countries at different stages of development and with different economic institutions. An important finding is that, as

\footnotetext{
61 "U.S., Others Suspend ITA Talks to Pressure China to Soften its Stance", Inside US Trade, July 29, 2013: page 2. ${ }^{62}$ As argued in Curtis, J., 2013, Trade and Innovation: Challenges and Policy Options, background paper for Expert Group 6 meeting, ICTSD, Geneva, June 6-7.
} 
far as domestic production, innovation and trade in electronics products is concerned, the costs of India's ITA participation seem to have substantially exceeded any gains. Current attempts to broaden the ITA list of products need to acknowledge that, without such reciprocity, it would be unrealistic to expect further progress in trade liberalization in this important and rapidly growing industry.

As India's experience with ITA demonstrates, the study of trade liberalization through plurilateral trade agreements needs to be nested in the larger context of latecomer industrial manufacturing and innovation. To broaden our knowledge of the overall effects of such trade agreements, it is important to conduct an impact analysis for other developing countries that have joined ITA. Such research is necessary to determine under what conditions special and differential treatment might be advisable.

Governments obviously need to make every effort to unblock barriers to growth and innovation through regulatory reform and industrial support policies. At the same time however, plurilateral trade agreements will strengthen the multilateral trading system only if they provide solutions for the asymmetric effects on cost structure and capabilities of different participants.

\section{Policy Implications}

1. By reducing barriers to trade in the critically important information and communications technology industry, the ITA could play an important role in facilitating the diffusion of innovation. This however would require reciprocity in the distribution of gains from trade liberalization.

2. The international community should acknowledge that participants in the ITA differ in their stage of development, their institutions, and their resources and capabilities. This may result in an unequal distribution of trade liberalization gains. Hence, developing countries who are latecomers to electronics manufacturing and innovation may not be able to reduce tariffs and other trade barriers at the same speed as leading economies.

3. All participants in current negotiations about an expanded ITA product list have a common interest in avoiding zero game or even negative game outcomes and the resultant trade conflicts. This implies that serious efforts are required to reduce asymmetric impacts of ITA. Thus, latecomers may deserve, under certain conditions, special and differential treatment. Such conditions may include a significant increase in the country's current account deficit due to rapidly rising imports; very high negative employment effects due to industry contraction; and negative effects on the effected industry's innovation capacity ${ }^{63}$.

4. An immediate and relatively easy response would be to extend the transition period during which latecomers can identify certain specified products as sensitive so that they qualify for a phased-in period of tariff reduction.

\footnotetext{
${ }^{63}$ As defined in Pisano, G.P. and W.C. Shih, 2012, Producing Prosperity. Why America Needs a Manufacturing Renaissance, Harvard Business Review Press, Boston, Mass., chapter 5.
} 
5. With the expansion of the ITA product list, it is time to reconsider whether ITA, like WTOGPA, should allow exceptions by way of offsets to the covered products.

6. Of the three basic principles that a country currently must abide by to become an ITA participant, it may be necessary to revisit the third principle that stipulates that "all other duties and charges (ODCs) must be bound at zero." ${ }^{64}$ As a temporary measure, latecomers to electronics manufacturing and innovation may need to adjust taxes to bring imports on par with domestic production through, for instance an import surcharge equal to the VAT.

7. Finally, as the focus of trade restrictions has shifted from tariffs to technical barriers to trade (TBTs) and non-tariff barriers (NTBs), those latter restrictions may well neutralize any positive effects of ITA-induced tariff reductions. Hence, it is necessary to put in place effective governance mechanisms as part of ITA-2 follow-up negotiations to ensure that the surge of NTBs and TBTs does not constrain access of developing countries' companies to the markets in the US, the EU and Japan.

\footnotetext{
${ }^{64}$ The first two requirements are: 1) all products listed in the Declaration must be covered, 2) all must be reduced to a zero tariff level. For details, seehttp://www.wto.org/english/tratop_e/inftec_e/itaintro_e.htm.
} 